Katarzyna Szalewska

Wydział Filologiczny

Uniwersytet Gdański

e-mail: k.szalewska@ug.edu.pl

\title{
Absolutna horyzontalność - wyobraźnia topograficzna i dyskurs krytyczny w Ameryce Jeana Baudrillarda
}

Zrodzona z bezkresnych wzgórz Teksasu i sierry Nowego Meksyku nostalgia [...] - z tej podróży trzeba by nakręcić totalny film drogi w rzeczywistym czasie jej trwania [...] i odtworzyć go potem u siebie [...] - by odnaleźć magię autostrad i odległości, zimnego alkoholu na pustyni i prędkości $[\ldots]^{1}$

- pisze Jean Baudrillard w eseju Ameryka, tekście znanym i wielokrotnie omawianym pod kątem socjologii ponowoczesnych społeczeństw, upadku tradycyjnej estetyki czy diagnoz kultury popularnej. Jednak odczytanie tego klasycznego dziś już quasi-reportażu w kontekście zwrotu topograficznego pozwala zauważyć inne jeszcze aspekty Baudrillardowskiej refleksji. Ameryka $\mathrm{w}$ perspektywie francuskiego myśliciela to przede wszystkim wielkie laboratorium testowania jednocześnie prymitywnych i przyszłych form życia zbiorowego, ale też ekran, na który rzutowane jest życie społeczne, analizowane przez Baudrillarda z uwzględnieniem czynnika spacjalnego. Przestrzeń staje się matrycą, poprzez którą widziane są i poddawane krytyce poszczególne aspekty organizacji politycznej, socjologicznej czy kulturowej. Diagnozy stawiane przez Baudrillarda wyłaniają się jako efekt badań nad Ameryką przeprowadzonych $\mathrm{z}$ użyciem instrumentarium topograficznego, a i samo, tak specyficzne przecież, imaginarium filozofa określić można mianem wyobraźni spacjalnej, wyczulonej na przestrzeń odbieraną w wielo-

1 J. Baudrillard, Ameryka, przeł. E. Lis, Warszawa 1998, s. 7. 
zmysłowej percepcji. Symptomem tego jest choćby bardzo idiolektyczny styl twórczości Baudrillarda, typ pisarstwa, który w Ameryce konkretyzuje się właśnie $\mathrm{w}$ metaforyce powiązanej z przestrzenią.

Interesująco też przedstawia się lektura wspomnianego eseju w kontekście Widzeń nad Zatoka San Francisco Miłosza. Te, wydane w 1969 roku, czyli siedemnaście lat przed Ameryka, okazują się bowiem w wielu miejscach prekursorskie wobec znanych diagnoz Baudrillarda.

Nie, nie są moją specjalnością pocztówkowe opisy. A jednak gnębi mnie dziewiczość tego kraju, dziewiczość w tym sensie, że jakby czekał na imiona. Nie był powoli, stopniowo, ujmowany w słowa przez wieki, a jeżeli ktoś starał się przetłumaczyć go na słowa, przemiany były tak szybkie, dwadzieścia lat tak bardzo równały się dwustu latom gdzie indziej, że zaraz znów przygotowywała się pusta tablica ${ }^{2}$

- pisze Miłosz, a "gnębienie", które diagnozuje, jest także motorem napędowym dyskursu Baudrillarda. Oba teksty funduje inicjacyjny wobec narracji gest postawienia się Europejczyka wobec krajobrazu amerykańskiego, refleksyjnego ,jj" wobec milczącej przestrzeni. Taki dialog obu pisarzy fascynuje, ich eseje wyrastają z uwiedzenia kontynentem i podjęcia wyzwania "pustej tablicy".

Baudrillard określa amerykański krajobraz mianem „horyzontalności absolutnej" 3 i w tym tkwi jego zasadnicza odrębność od pejzażu europejskiego. Europą bowiem rządzi perspektywa wertykalna - sankcjonowana przez budowle średniowieczne, strzeliste katedry powstające ku chwale bożej, tradycja architektury wyrażającej idee, powiązanej z metafizyką obecności i wiarą w transcendentny wymiar rzeczywistości. Trafnie wyraża to Miłosz, pisząc, że:

Cywilizacja europejska wspierała się na pewnych przestrzennych odpowiednikach czy przekładach praw religijnych. Były to zarówno układy pionowe: Niebo, Ziemia, Piekło, jak i poziome - niebezpieczne wyprawy rycerzy w poszukiwaniu Graala, legenda wojen krzyżowych o grób Chrystusa czy też podróże po trudnych do przebycia drogach, ilustrujące powolny postęp duszy ku zbawieniu mimo osaczających ją diabelskich pokus ${ }^{4}$.

Mit amerykański także nie pozostaje bez związku z parametrem przestrzennym, czego manifestacją jest kariera westernu, ale przede wszystkim kina drogi, w którym krajobraz pełni funkcję symbolu ludzkiego losu,

\footnotetext{
2 Cz. Miłosz, Widzenia nad Zatoką San Francisco, Kraków 1989, s. 9.

3 J. Baudrillard, Ameryka, s. 9.

${ }^{4}$ Cz. Miłosz, Widzenia nad Zatoka San Francisco, s. 190-191.
} 
społecznych stosunków i stanowi element konstruowania narracji tożsamościowej. Jednak mimo to Ameryka jest przestrzenią horyzontalną, a więc (post)laicką, (post)metafizyczną i (post)demokratyczną. To dlatego jedynym prawdziwym zdarzeniem na tym kontynencie okazuje się, jak pisze francuski obserwator, „wydarzenie pustyni" ${ }^{5}$. Pustynia stanowi słowo klucz eseju Baudrillarda, podstawową figurę spacjalną, organizującą opowieść o Ameryce. Pojmowana nie jako kategoria geograficzno-biologiczna, lecz jako „wydarzenie", będące symptomem współczesnej kultury, staje się przykładem roli metaforyki przestrzennej $\mathrm{w}$ budowaniu dyskursu krytycznego. Innym jej świadectwem może być choćby taki fragment:

Monument Valley: językowe bryły nagle w erekcji, później poddane tysiącletnim sedymentacjom nieuchronnej erozji, które właśnie jej zawdzięczają swą transwersalną głębię (sens rodzi się z erozji słów, znaczenia z erozji znaków), i które dzisiaj, jak cała kultura, skazane są na los rezerwatów ${ }^{6}$,

w którym określenia z pól semantycznych związanych z geografią, geologią i biologią zostają zaadoptowane do analiz zjawisk z zakresu kultury i socjologii.

Dzieje się tak z uwagi na specyfikę fenomenu Ameryki, który jakby „domaga się" innego języka opisu, a z pewnością porzucenia sposobów deskrypcji wykształconych w przestrzeni Starego Kontynentu. I u Miłosza, i u Baudrillarda widoczna jest kompozycja narracji oparta na dualizmie perspektyw patrzenia z obu brzegów oceanu, zestawiania tego, co swojskie, z tym, co inne, egzotyczne, a przez to jednocześnie pociągające i przerażające.

Dały mi wiele szczęścia ulice Paryża, doliny i pagórki francuskiej prowincji, gdzie łupkowy dach $w$ kępie zieleni, pole, mostek, gaj pękały niemal od gęstości swojego niepowtarzalnego, poszczególnego istnienia, wyładowując każdy kilometr nadmiarem rzeczy do obejrzenia i do dotknięcia. To co innego, niż przelatywać trzysta mil autostradami Kalifornii wśród groźnych, spotworniałych widoków, niesamowitych barw światła na gołych górach ${ }^{7}$

- wyznaje Miłosz, dając tym samym świadectwo i komparatystycznego myślenia o obu kontynentach ${ }^{8}$, i ich opozycyjnego kategoryzowania. Europa to u obu pisarzy nadmiar rzeczy, szczegół, konkret artefaktów, w Ameryce zaś

\footnotetext{
5 J. Baudrillard, Ameryka, s. 10.

6 Tamże.

7 Cz. Miłosz, Widzenia nad Zatoka San Francisco, s. 34-35.

8 Nie podejmuję się w tym miejscu pogłębionej analizy Miłosza doświadczenia Ameryki. Zrobiła to wyczerpująco Ewa Kołodziejczyk - zob. tejże, Amerykańskie powojnie Czesława Miłosza, Warszawa 2015.
} 
te właściwości zastępuje nadmiar przestrzeni przy niedoborze rzeczy, ogół, abstrakcja, szybkość i dominacja ekofaktów.

Nie pozostawia to jednak Baudrillarda i Miłosza niewrażliwymi na sensoryczny wymiar Ameryki. Ten pierwszy zauważa, że:

Cisza pustyni jest także wizualna. Buduje ją zasięg spojrzenia, które nigdzie nie znajduje punktu, od którego mogłoby się odbić. W górach nie można uchwycić takiej ciszy, ponieważ ich kształt wyje. Aby naprawdę była cisza, czas musiałby przybrać również horyzontalną postać, przyszłość nie mogłaby rozbrzmiewać jego echem ${ }^{9}$.

Baudrillard nieustannie poszukuje analogii dla oglądanego pejzażu, znajdując ją w tym, co znane, $w$ formach charakterystycznych dla krajobrazu Europy. Praca spojrzenia przyzwyczajonego do określonego typu percepcji zostaje unieważniona przez amerykańską „erozję sensów”. Nowy Kontynent autor Precesji symulakrów opisuje w jego opozycji do Starego, Ameryka jest więc nie-Europą, pustynia - nie-górami. Wizualność pustynnej ciszy, o której pisze, ponownie łączy się z horyzontalnością, dla której pustynia jest wzorcową formą, ale także z wymiarem temporalnym. Strzelistość europejskich budowli znajduje odpowiednik w wertykalnym ułożeniu gór, przyroda zdaje się odpowiadać na wyzwanie tradycyjnej metafizyki i pojmowania czasu, w którym możliwe do usłyszenia są echa przyszłości i przeszłości. Ameryka tę temporalną pewność unieważnia, miasta bez centrum i krajobrazy bez wzniesień oznaczają odrzucenie znanych chronotopów.

Bardzo wyraźnie to przeciwstawienie konstruuje Miłosz, pisząc, że:

Krajobrazy Europy są metaforą jej ciągłej przeszłości, jej partykularyzmów, uczuciowych przywiązań do tego, co głupio lokalne, powolnego lepienia się grodów, ksiąstewek w większe zespoły. Miasto-abstrakcja i abstrakcyjne teatrum Natury jako coś, co się mija, są metaforą Ameryki. Wszystko jest poza nim i pasażer samolotu patrzy na telewizję, kiedy przesuwają się pod nim łańcuchy górskie, pustynie, uprawne równiny ${ }^{10}$.

Europa jest logocentryczna - schronieniem dla logosu i jego ucieleśnieniem staje się jej architektura, a nawet przyroda. Myśląc bowiem o pejzażach europejskich, Miłosz widzi przede wszystkim krajobrazy kulturowe. W Ameryce obaj twórcy utopijnie odnajdują iluzję Natury w stanie czystym. Konstruując jednak ten mit, odchodzą od Rousseau'skiej wizji powrotu do Natury czy romantycznych wyobrażeń przyrody jako księgi pełnej znaków i zaszyfrowanych correspondances. Krajobraz w Widzeniach nad Zatoka San Francisco

9 J. Baudrillard, Ameryka, s. 13.

10 Cz. Miłosz, Widzenia nad Zatoka San Francisco, s. 35. 
i Ameryce jest bezwzględnym, milczącym Innym, wobec którego kapitulują znane modele narracyjne. Nie można go uchwycić, uobecnić, można próbować jednak dokonać jego wątpliwej reprezentacji. I Baudrillard, i Miłosz poszukują analogii w medium telewizji i filmu oraz - zazwyczaj $\mathrm{w}$ duchu negacji - w odniesieniu do metaforyki teatralnej, scenicznej.

Cud włoski: cud sceny.

Cud amerykański: cud obsceniczności.

Rozpusta sensu przeciw pustyniom braku znaczenia ${ }^{11}$

- u Baudrillarda uwidacznia się bardzo wyraźna tendencja, by nie powiedzieć: maniera stylistyczna, polegająca na dążeniu ku aforyzmowi, próbie zamknięcia w zwięzłej, często, tak jak w tym wypadku - opartej na kontraście - formule równocześnie percepcji i refleksji. Powyższy fragment, w którym Baudrillard operuje paralelizmem składniowym i antytezą, wydaje się quasi-gnomicznym ujęciem zasadniczej dla wspomnianych pisarzy opozycji między europejskością a amerykańskością. Krajobraz jest przy tym charakteryzowany w kategoriach kulturowych, zostaje bowiem przyrównany do sceny.

Tak jak Miłosz zrównuje teatr Miasta z teatrem Natury, tak i Baudrillard widzi w pejzażu Europy synekdochę totum pro parte - całość estetyczną, której częścią w innym wymiarze jest scena włoska. Ta zaś charakteryzuje się i ograniczeniem, i kadrowaniem pola widzenia publiczności (która ma koncentrować się na określonym jej wycinku), i przepychem znaczeń niejako skondensowanych $w$ tak skonstruowanym „pudełku”. Jednocześnie metaforyka teatralna $\mathrm{w}$ tym wypadku pozwala wydobyć sensy związane ze sztucznością, archaicznością, przynależnością europejskiej estetyki i natury do tradycyjnego, a nie ponowoczesnego świata.

Ameryka jest obsceniczna, co w filozofii Baudrillardowskiej oznacza widzialność niewykadrowaną, nieoswojoną przez kulturowe, europejskie sposoby patrzenia, pejzaż wystawiony na pokaz. Jak pisze Michał Paweł Markowski:

Obsceniczność, która obwieszcza kres sceny (podział na aktorów i widzów, przestrzeń prywatną i publiczną) jest hiperwidzialnością: rzeczy stają się bardziej widzialne niż widziane, to znaczy niemal przezroczyste, absolutnie bliskie, pozbawione odległości i perspektywy. [...]. Dystans zostaje zniesiony, a z nim zarówno przestrzeń imaginarium, jak fantazmatu ${ }^{12}$.

11 J. Baudrillard, Ameryka, s. 16.

12 M.P. Markowski, Baudrillard: słownik, w: J. Baudrillard, Ameryka, s. 187. 
Scena włoska uruchamia grę wnętrza i zewnętrza, iluzji i realności, co umożliwia wytworzenie się tajemnicy, zostawia miejsce na domysł, marzenie, pożądanie. Scena amerykańska jest anty-sceną, gdyż zniesienie podziału na widzianych i patrzących oraz likwidacja ograniczających pole spojrzenia kurtyn i ścian sprawia, że kategorię miejsca zastępuje kategoria przestrzeni, a brak zasłony uniemożliwia, jak pisze Markowski, powstanie sekretu, a wraz $\mathrm{z}$ nim fantazmatu. Baudrillard łączy te wyobrażenia spacjalne z filozofią znaku, a tym samym tworzy korespondencje między pożądaniem, teatrem, rozpustą i nadmiarem znaków oraz obsceną, pustynią i brakiem znaczenia.

Zapewne ten kontynent oglądany z samolotu jest pustką [...] wszystkie miasta są jednym miastem, wszystkie szosy jedną szosą, wszystkie sklepy jednym sklepem i przesunięcie się o tysiąc mil traci sens, bo gdziekolwiek wyruszyć, natrafia się na tę samą toczącą się ścianę ${ }^{13}$.

Krajobraz amerykański dzieli, według Miłosza, bolączki nowoczesnej kultury, wraz z jej unifikacją. W opisie autora Widzeń nad Zatoką San Francisco znika europejski partykularyzm, ale też lokalność, do której wykształcenia potrzebna jest różnica. Baudrillard wiele miejsca poświęci, nie tylko w Ameryce rzecz jasna, deskrypcji symptomów ponowoczesności, symulakryczności współczesnych mu przestrzeni. Brak genius loci, jaki uwidacznia się w Ameryce, by niebawem stać się cechą całego zindustrializowanego świata, obaj myśliciele widzą w kategoriach upadku doświadczenia i kryzysu tożsamości, dla której aspekt przestrzenny jest przecież kluczowy. Prędkość przeciwstawia się zadomowieniu, zakorzenienie wymaga oswojenia wybranego i rozpoznawalnego w przestrzeni miejsca - „pustka” Ameryki, jej „pustynność”, która fascynuje Baudrillarda, wpisuje się nie tylko w filozofię prędkości Paula Virillo ${ }^{14}$, ale także w znane rozpoznania Marca Augé ${ }^{15}$ dotyczące nie-miejsc jako właściwego pejzażu ponowoczesności.

Baudrillard formułuje wiele przemyśleń dotyczących nie-miejsc właśnie - Amerykę ogląda w ruchu, w samolocie lub samochodzie, zawsze w przestrzeni tranzytywnej, tyle że w wypadku Nowego Kontynentu nie ma mowy o figurze przejścia, transgresji: jedno nie-miejsce przechodzi w kolejne, bez obietnicy dotarcia do celu czy w ogóle jego istnienia. To w tym także spełnia się "absolutna horyzontalność” czy też pustynna pustka, to słowo bowiem

\footnotetext{
13 Cz. Miłosz, Widzenia nad Zatoka San Francisco, s. 59.

14 Zob. P. Virillo, Prędkość i polityka, przeł. S. Królak, red. K. Nadana, Warszawa 2012.

15 Zob. M. Augé, Nie-miejsca. Wprowadzenie do antropologii hipernowoczesności, przeł. R. Chymkowski, przedm. W.J. Burszta, Warszawa 2010.
} 
pojawia się i na kartach Ameryki (tu bardzo często zresztą), i w prekursorskich Widzeniach nad Zatoka San Francisco, gdzie czytamy np.:

posuwamy się przed siebie w pustce ustawicznej, od czasu do czasu zaludnionej, niekiedy wypiętrzającej się $\mathrm{w}$ miasta. [...] Miasta: taśma freewayu przenosi nas ponad symetrią ich pociętego $\mathrm{w}$ prostokąty obszaru, ale są tylko przeszkodą, bo zmuszają do zmniejszenia szybkości i przystawań na światłach. Podróż odbywa się w środku maszyny, $\mathrm{z}$ nią tylko $\mathrm{w}$ intymnym kontakcie, mierzona strzałką szybkościomierza i pełznącymi cyframi przebitych mil, natomiast to, co na zewnątrz, miga, ukazuje się i znika, srebrnawe, odrealnione, ekran ${ }^{16}$.

Słowa Miłosza, z drobną zmianą stylistyczną, mogłyby równie dobrze stanowić fragment późniejszego przecież eseju Baudrillarda. Tu także wyrażona zostaje fascynacja prędkością i samochodem jako jej narzędziem, symbolem, ale też ważnym elementem zarówno kultury amerykańskiej, jak i tamtejszego modelu percepcji rzeczywistości.

Kultura europejska wytworzyła figurę flâneura, usankcjonowaną przez tradycję Baudelaire'owską i Benjaminowską, kontynuowaną w niezliczonych realizacjach literackich i filmowych. Flâneur jest figuracją podmiotowości dziewiętnastowiecznej (wraz z jej postępującą urbanizacją) i wczesnomodernistycznej. Przechadzając się po specjalnie jakby ku temu przeznaczonych bulwarach Paryża, ogląda miasto w jego fantazmatycznym wymiarze - witryny, kawiarnie, dandysów. Wszystko odbywa się niespiesznie, $\mathrm{w}$ tempie dostosowanym do procesu percypowania estetycznego i zdarzeniowego wymiaru metropolii oraz procesu intelektualizacji doznań. W Ameryce flâneur przesiada się natomiast do samochodu, chodzenie zastępuje jazda, żółwie tempo - prędkość, bulwary i pasaże - "taśma freewayu”, samego flâneura wreszcie - konsument galerii handlowych ${ }^{17}$. Figura samochodu oznacza u Baudrillarda model ponowoczesnego doświadczenia, a właściwie jego upadku w dobie szybkości niesprzyjającej i namysłowi, i kształtowaniu trwalszych, niż chwilowe, przeżyć, oraz wobec obsceniczności symulakrów, zaistniałej w miejsce aury oryginału. Samochód zmienia wreszcie sposób kadrowania spojrzenia, które widzi przestrzenie pokawałkowane, umykające,

\footnotetext{
16 Cz. Miłosz, Widzenia nad Zatoka San Francisco, s. 131.

17 Jak pisze Zygmunt Bauman: „Postmodernistyczni flâneurs odwiedzają codziennie czy też raz w tygodniu promenady pełne sklepów, miejscowe kościoły wyznania flaneryzmu, unikając jak tylko można wszelkiego kontaktu z leżącymi pomiędzy nimi ulicami, łowiskami ich przodków (bardziej szczęśliwi spośród nich mogą pozwolić sobie na doroczną pielgrzymkę do wakacyjnych plaż, głównych świątyń i miejsc kultu owego wyznania)" [Z. Bauman, Przedstawienie na pustyni, przeł. M. Kwiek, w: „Drobne rysy w ciagłej katastrofie...". Obecność Waltera Benjamina w kulturze wspótczesnej, red. A. Zeidler-Janiszewska, Warszawa 1993, s. 82].
} 
nakładające się jedne na drugie. Patrzenie zostanie wyparte przez spojrzenia właśnie - migawkowe, nieuważne, skupione na tym, co najbardziej widoczne.

„Wszystko znika coraz prędzej we wstecznym lusterku pamięci"18 - pisze Baudrillard, a fraza ta podsumowuje $\mathrm{z}$ mocą aforyzmu właściwości typu percepcji dostosowanej do ponowoczesnego krajobrazu. Przede wszystkim więc raz jeszcze pojawia się słowo klucz Ameryki - zanik. W innym miejscu eseju czytamy przecież, że pustynia jest „,[...] ekstatyczną krytyką kultury, ekstatyczną formą zanikania"19. Dokonując krytyki kultury za pomocą pojęcia geograficznego, Baudrillard ubiera dyskurs filozoficzny w kształty wyobraźni topograficznej. Pozioma przestrzeń pustyni jest anty-logocentryczna, poza-słowna, stanowi przeciw-reprezentację. Działanie pustyni spełnia się w wymiarze apofatycznym, staje się ona kontr-znakiem europejskiej różnorodności pejzażu. Jeśli ten przywodzi na myśl romantyczne teorie symbolu, z konotowanymi przez niego pojęciami uczestnictwa, obecności i korespondencji, to Ameryka jest de Manowską alegorią, grą znaków pozbawionych swoich znaczonych. Choć i tak pojęta alegoria nie jest odpowiednią formułą dla Ameryki Baudrillarda, zakłada bowiem działanie retoryki czasowości. Tymczasem zanik dokonuje się $\mathrm{w}$ lusterku pamięci - perspektywę temporalnego continuum wyklucza estetyka prędkości, której znakiem staje się samochód. Pęd przeciwdziała pamiętaniu, a motyw lusterka ${ }^{20}$ metaforycznie spaja różne wątki Baudrillardowskiej refleksji - zanik, prędkość, pokawałkowanie percepcji i niespójność doświadczenia oraz symulakryczność lustrzanej przestrzeni, budowanej z niezliczonych odbić nieistniejącego oryginału.

18 J. Baudrillard, Ameryka, s. 96.

19 Tamże, s. 12.

20 Interesujące jest zestawienie motywu lusterka samochodowego u Baudrillarda $\mathrm{z}$ wierszem Adama Zagajewskiego Lusterko samochodu. W liryku tym „[z]estawienie lusterka samochodu i sławnej gotyckiej katedry pozwala dostrzec nie tylko paradoks chwilowego zawierania się wielkiego w małym. [...] Te dwa przedmioty, tak ogromnie od siebie różne, a w błysku jednego spojrzenia złączone w całość (skoro jeden zmieścił się w drugim), możemy potraktować jako hasła wywoławcze sygnalizujące różne strony wyobraźni poety, różne tematyczne inspiracje jego wierszy. Lusterko samochodu i gotycka katedra dają się wpisać w ciąg różnorodnych przeciwstawień, między którymi powstają napięcia dynamizujące obraz świata ukazywany przez poetę. $\mathrm{Z}$ opozycji zarysowanej $\mathrm{w}$ wierszu możemy wyprowadzić szeregi przeciwstawnych skojarzeń: cywilizacja współczesna - długie wieki europejskiej tradycji; technika - sztuka; ruch auta - bezruch potężnej budowli; podróż - życie osiadłe; codzienność - odświętność religijnego obrzędu, czyli profanum - sacrum; przedmiot użytkowy - bezinteresowany charakter piękna; styl niski (potoczność) - styl wysoki (wzniosłość)" [M. Czermińska, Co może się zmieścić w lusterku samochodu?, w: Sztuka interpretacji. Poezja polska XX i XXI wieku, red. D. Szczukowski, G.B. Tomaszewska, Gdańsk 2014, s. 291]. Nietrudno zauważyć, jak znaczący jest wybór katedry w Beauvais jako tematu epifanijnego wiersza przez Zagajewskiego i pustyni jako nadrzędnej figury krytycznego eseju przez Baudrillarda. 
Baudrillard [...] sugeruje, że „Ameryka" podjęła się urzeczywistnienia utopii, realizowania wszystkiego w osobliwym fatalizmie symulacji. W Ameryce kultura jest więc „przestrzenią prędkością, kinem, technologią". Tych pustych krajobrazów pustyni doświadcza się, jadąc samochodem przez jej olbrzymie przestrzenie; podróż przypomina „linię ucieczki”. Pustynia jest metaforą nieskończonej przyszłości, prymitywnego społeczeństwa przyszłości, równoznacznej z wymazaniem przeszłości i triumfem momentalności nad czasem jako głębią [...]. Jazda przez pustynię to zostawienie przeszłości z tyłu, za sobą, to nieustające połykanie przestrzeni, oglądanie w kadrze szyby samochodu ciągle przemykającej pustki $[\ldots]^{21}$.

Opozycja poziomu i pionu, płaszczyzny (, absolutnej horyzontalności” i głębi), a także powiązanej z tym zestawieniem pary pojęć szybkości i pamięci, teraźniejszości i historii, stanowi intelektualną ramę także dla rozważań poświęconych miejskości, jak choćby w poniższym fragmencie:

W Paryżu, mieście drobnych posiadaczy, niebo nigdy nie odrywa się od ziemi, nie szybuje, zamknięte $\mathrm{w}$ dekoracjach obolałych budynków, które dają sobie nawzajem cień, zamiast być dla siebie przyprawiającym o zawrót głowy lustrem, jak to się dzieje w Nowym Jorku [...]. Kiedy zestawi się paryską La Defense z downtowns i amerykańskimi drapaczami chmur, traci ona przysługującą jej w Europie pozycję architektonicznego szczytu wertykalności i nieumiarkowania, jej budynki wyglądają jak umieszczone na włoskiej scenie, w zamkniętym, ściśle ograniczonym przez peryferyjny bulwar teatrze. To rodzaj francuskiego ogrodu: bukiet gmachów przewiązanych wstążką ${ }^{22}$.

To przykład jednej z pozornych niekonsekwencji, licznych w eseju utrzymanym w stylu oksymoronicznym, nastawionym na wyraziste i konceptualne sformułowania. $Z$ jednej strony pejzaż Europy wyznacza układ wertykalny, z drugiej okazuje się, że paryska dzielnica wieżowców nie dorównuje wysokością swoim amerykańskim odpowiednikom. Chodzi tu jednak o odmiennie rozumianą strzelistość, która $\mathrm{w}$ architekturze Nowego Kontynentu nie oznacza wcale zbliżenia ku perspektywie niebiańskiej (symbolicznie więc: boskiej, teleologicznej itd.). Jak pisze Tadeusz Sławek:

Miasto ponowoczesne jest postacią pustki. Baudrillard określając amerykańskie miasta jako „pustynię", przypuszczalnie nazywa otchłań (Abgrund), w której Nietzsche dopatruje się jedynych paradoksalnych fundamentów rzeczywistości po śmierci Boga. Świat ten pozbawiony jest przede wszystkim charakterystycznych punktów rozpoznawczych pozwalających orientować się w przestrzeni,

21 J. Urry, Socjologia mobliności, przeł. J. Stawiński, Warszawa 2009, s. 93.

22 J. Baudrillard, Ameryka, s. 27. 
a ponieważ zakłócenia obejmują tak sferę bezpośredniego otoczenia (góra/dół), kosmosu („,odpętanie ziemi od słońca”, jak i dalszą perspektywę widzenia („wymazanie horyzontu"), „otchłań" nie może być rozumiana wyłącznie jako wyznaczona przez kierunek pionowy (przepaść), lecz równie dobrze może mieścić się w kategoriach ruchu poziomego zaprzeczając klasycznemu rozumieniu głębi. „Teologiczna" urbanistyka Nietzschego nie jest już w stanie rozróżnić bezbłędnie głębi i powierzchni, fasady i struktury konstrukcji, miasta od tego, co miastem nie jest ${ }^{23}$.

Pustynia (a pod tym pojęciem Baudrillard rozumie także fenomen amerykańskich miast) wyklucza ruch wznoszący, ale też przeinterpretowuje fabułę drogi. Zniesieniu ulegają europejskie konotacje ruchu z pielgrzymowaniem, dojrzewaniem wewnętrznym czy przechodzeniem rites de passage. Brak „teologicznej” urbanistyki oznacza także brak teleologii ruchu, który staje się przemieszczaniem dla samej prędkości, wśród takich samych miast. W nich zaś nie ma już fasad budynków, które obiecywałyby głębię ${ }^{24}$ (a więc przejście od znaku do znaczenia), pozostają ekrany i pustynnienie, oznaczające stałą erozję sensu:

Winda i metro nie istnieją w Los Angeles. Nie istnieje wertykalność ani underground, nie istnieje chaos ani zbiorowość, nie ma ulic ani fasad, ale także centrum lub pomnika: przestrzeń fantastyczna, fantasmagoryczne i nieciągłe następstwo wszystkich znaków bez hierarchii - feeria niezróżnicowania, feeria niezróżnicowanych powierzchni - potęga czystej rozciągłości, jaką można odnaleźć na pustyniach. Potęga formy pustynnej: zacieranie się śladów na pustyni, signifie znaków w miastach, wszelkiej psychologii w ciałach ${ }^{25}$

- czytamy w Ameryce. Baudrillard tworzy wyliczenie konstytutywnych elementów miejskości pojmowanej z europejskiej perspektywy. Ulice, fasady, centrum i pomniki to znaki geometryzacji wyobraźni urbanistycznej, jej zdolności do przestrzennego wyrażania ratio, a jednocześnie prawideł życia społecznego, wyraz spacjalizacji wspólnoty ludzkiej (centrum) i przejaw myślenia historycznego, właściwych kulturze form upamiętniania (pomniki). W wypadku braku tych właśnie znaków urbanistycznego języka Europej-

\footnotetext{
23 T. Sławek, Akro/nekro/polis: wyobrażenia miejskiej przestrzeni, w: Pisanie miasta - czytanie miasta, red. A. Zeidler-Janiszewska, Poznań 1997.

24 Wojciech Kalaga pisze, że „aktywność twarzy i fasady odwołuje się do podstawowej dychotomii wnętrza i zewnętrza i przejawia się jako odsłanianie tego, co ukryte w głębi, co niewidoczne, lub co byłoby niewidoczne, gdyby właśnie nie fakt eksternalizacji" [W. Kalaga, Twarz, maska, fasada, „Kultura Współczesna” 2006, nr 3, s. 15-16].

25 J. Baudrillard, Ameryka, s. 164.
} 
czyk doznaje konfuzji odbiorczej, przestrzeń okazuje się wyrażona w innej mowie, miasto traci czytelność ${ }^{26}$.

Proces translacji Ameryki na znaki znane z europejskiego języka miasta, którego podejmują się Baudrillard i Miłosz, musi zakładać ewolucję symboli - fetyszy miejskiej kultury urbanistycznej - jaka dokonała się w postmodernistycznej estetyce. Na jeden z jej aspektów zwraca uwagę John Urry, badacz socjologii mobilności, projektowanej w pewnym sensie przez Baudrillarda:

W społeczeństwach nowoczesnych dominują metafory zegara, różnych typów mechanizmów i obiektywu fotograficznego. Natomiast dla społeczeństw ponowoczesnych płodną metaforą byłby hologram. [...] Metaforę hologramu można przeciwstawić metaforze obiektywu fotograficznego, która dominowała w "nowoczesnej" epistemologii i estetyce. W obiektywie mamy do czynienia ze ściśle jednostkowym przyporządkowaniem każdego punktu na przedmiocie punktowi ukazującemu się na płycie czy filmie. Metafora obiektywu zakłada sekwencyjność, oddzielenie części i całości oraz względnie rozciągły proces w czasie zegarowym niezbędny do wytworzenia obrazu ${ }^{27}$.

Rytm miasta modernistycznego wybija miejski zegar ${ }^{28}$, symbol czasu świeckiego (wypierającego czas sakralny odmierzany przez dzwony kościelne), zinstytucjonalizowanego, poddanego działaniom ekonomii i władzy politycznej. Linearność i cykliczność urbanistycznego rytmu ${ }^{29}$ pozwalają na pamięć, na kumulowanie wiedzy o przeszłości miasta. Natomiast drugi z symboli społeczeństwa nowoczesnego - aparat fotograficzny - jest potwierdzeniem modernistycznego okulocentryzmu, estetyzacji spojrzenia flâneura na teatr ulicy, ale także dominacji perspektywy temporalnej. Inaczej hologram - opisywana przez Baudrillarda nadprodukcja obrazów stanowi przełom epistemologiczny (poznanie nie-rzeczywistego, reprezentacja bez oryginału) i estetyczny, ale również temporalny - hologram wprowadza miasto w wieczną teraźniejszość.

Architektura francuska (pars pro toto europejska) w powyższym fragmencie z eseju Baudrillarda raz jeszcze okazuje się dekoracją na włoskiej scenie,

26 Koncepcję czytelności miast tworzy Kevin Kynch, rozumiejąc ją jako „łatwość, z jaką poszczególne części miasta mogą zostać rozpoznane i zorganizowane [w umyśle odbiorcy - dop. K.Sz.] według koherentnego wzoru" [tłumaczenie własne].

27 J. Urry, Socjologia mobliności, s. 172-173.

28 O czasie miejskim piszę szerzej w innym miejscu. Zob. K. Szalewska, Rytmoanaliza - o miejskich zegarach i zmystach, w: tejże, Urbanalia - miasto i jego teksty. Humanistyczne studia miejskie, Gdańsk 2017.

29 Rozważania na temat rytmów czasu linearnego i cyklicznego w życiu miejskim zob. H. Lefebvre, Rhythmanalysis. Space, Time and Everyday Life, trans. S. Elden, G. Moore, introd. S. Elden, London-New York 2004. 
której ściany przytłaczają zapisaną w nich historią, a fasady przemawiają nadmiarem znaków. Koncept teatralności pejzażu Europy zostaje wzmocniony przyrównaniem go do francuskiego ogrodu, co wzmaga sztuczność krajobrazu, ale też jego celowość. Inaczej zgoła wyglądają miasta amerykańskie. Miejskość nie jest tu odgraniczona od nie-miejskości, a więc natury. Figura francuskiego ogrodu (z przywoływaną $\mathrm{w}$ tym wyobrażeniu ideą oświeceniowego ratio, geometryzacji i urbanistycznego planu) ustępuje miejsca metaforze pustyni - estetyka klasycystycznego ładu zmienia się we właściwą ponowoczesności estetykę prędkości i zaniku. Wertykalność amerykańskich wieżowców jest złudna, gdyż spojrzeniem przechodnia rządzi nie strzelistość (nakazująca spoglądanie w górę), lecz nadmiar miejskich ekranów. Nowojorskie budynki są, jak pisze Baudrillard, lustrem - dla siebie nawzajem, ale także dla przechodnia, którego spojrzenie rozbija się na zmultiplikowane powielenia kawałków architektury.

Europejski flâneur przeglądał się $\mathrm{w}$ witrynach, zachwycał panoramami i szkłem pasaży, uosabiając tym samym fascynację rodzącej się nowoczesności możliwościami wielkomiejskiej architektury. Niespieszny przechodzień stanowi metaforę narcystycznej wyobraźni urbanistycznej ${ }^{30}$, która chce dopasować miasto do perspektywy podmiotowej - flâneur pragnie przejrzeć się $\mathrm{w}$ miejskim lustrze i jednocześnie uczynić $\mathrm{z}$ miasta miniaturę, obraz skończony, możliwy do całościowej percepcji, obiekt estetyczny, $\mathrm{w}$ kontakcie $\mathrm{z}$ którym doświadczenie odbywa się $\mathrm{w}$ ustanowionych ramach (przez Baudrillarda wyobrażonych w figurze wstążki opasającej bukiet budynków).

W Ameryce natomiast podmiot gubi się w kolejnych odbiciach, które prowadzą tylko do rozbicia tożsamości, a nie jej uspójnienia w ekranach miasta $^{31}$. Te nie ukazują bowiem oblicza przechodnia, lecz wytwarzają kolejne

30 „Poprzez zmniejszenie całego świata, ukazanie go we fragmentach, Narcyz podkreśla jednocześnie swoją wielkość. [...] «Świat w miniaturze» wymaga zatem innego spojrzenia, bardziej przenikliwego, zaopatrzonego w szkło powiększające, a takie, moim zdaniem, jest właśnie spojrzenie miejskiego Narcyza. Wyobraźnia nie chce tutaj dążyć do schematu, który byłby podsumowaniem zdobytej wiedzy. Poszukuje raczej pretekstu, aby mnożyć wyobrażenia i jeśli tylko zostanie pobudzona przez obraz, podwyższa jego wartość. Marzyciel staje się bytem w swoim obrazie" [M. Nieszczerzewska, Narracje miejskiej wyobraźni, Poznań 2009, s. 131]. U Baudrillarda marzyciel byłby produktem obrazów, więźniem nieskończonej produkcji ikonicznej.

31 Tę prawidłowość amerykańskiej przestrzeni miejskiej zauważają liczni twórcy podejmujący temat doświadczania Ameryki. W tomie W Central Parku Wojciecha Karpińskiego czytamy: „Przespacerowałem się Wall Street, gdzie dokonałem poważnych transakcji. Odchyliłem głowę u stóp Chase Manhattan Bank i piąłem się ku niebu po wirujących piętrach. To nie tam zrozumiałem handlową potęgę miasta. Jego puls bije wszędzie. Rodzi się ze złożenia tak różnorodnych światów. Trzeba przejść się, kto ma siłę, po handlowych ulicach Lower East Side. Tak 
kopie dobrze znanych obrazów-kliszy. Hiperrzeczywistości ponowoczesnego polis nie da się ująć we "wstążkę", gdyż jej zasadą nie jest bukiet budynków, lecz ich symulakryczność. Baudrillard, uciekając przed mitem europejskim, wpada w mit amerykański. Patrzy na Nowy Kontynent jako przestrzeń znaną z filmów drogi - bezkresną, horyzontalną, pustynną lub pełną drapaczy chmur. Europa spełnia się dla niego w synekdosze (logos architektury jako reprezentant logocentryzmu kultury europejskiej), Ameryka - w metonimii (szeregu kolejnych zamienni połączonych związkami ikonicznymi, lecz nieprowadzących do oryginału dającego początek procesowi podmianek).

Właściwości te Baudrillard oddaje tworząc analogię ze sztuką filmową:

W Death Valley nie brakuje nawet filmowych skrótów. Bowiem cała jej tajemnicza geologia jest zarazem scenariuszem. Amerykańska pustynia odznacza się nadzwyczajną dramaturgią, ale nie teatralną, jak niektóre zakątki alpejskie, albo sentymentalną, jak las czy wioska. Nie jest także wyniszczona i monotonna jak lunarna pustynia australijska. Ani mistyczna, jak pustynie islamu ${ }^{32}$.

Jak wiadomo, w procesie okrzepnięcia mitu Nowego Kontynentu bardzo ważną rolę odgrywa kino, ze spetryfikowanymi już sposobami prezentacji amerykańskiego krajobrazu i jego roli w budowaniu narracji tożsamościowych (czego najlepszym przykładem, wspomniane przez Baudrillarda, kino drogi). Autor Precesji symulakrów (podobnie zresztą jak Miłosz w wielu fragmentach Widzeń nad Zatoka San Francisco) wpisuje się w określoną tradycję intelektualną, z właściwą dla niej wyobraźnią topograficzną.

Brak historii czytelnej w amerykańskim krajobrazie [o czym wspominają obaj twórcy - dop. K.Sz.] nie jest [...] odkryciem współczesności. Tę samą refleksję mieli pierwsi kolonizatorzy „dzikiego Zachodu”, którzy w dziewiętnastym wieku odkryli dzikie przestrzenie Yellowstone i Yosemite, porównywane przez

wyobrażam sobie unowocześnioną wersję przedwojennych Nalewek w Warszawie, setki sklepów i kramów. [...]. W Chinatown nie tylko je się chińskie potrawy, ale czyta chińskie gazety, ogląda chińskie filmy. [...]. W Little Italy, jak w tej prawdziwej, ludzie siedzą przed domami (w Nowym Jorku!) i gawędząc z sąsiadami przyglądają się przechodniom. [...]. Jak Nowy Jork zmienia się nie tylko zależnie od dzielnicy, ale i od pory dnia! Przez mgłę poranku widziałem, zmęczony nocną włóczęgą, życie spokojne, złożone. Godziłem się na wielowarstwowość, na wyrywkowość doznań. Świat dookolny był większy ode mnie, ale nie miażdżący. Nie wyczerpywałem sensu tego, co widziałem, a ono nie zamierało pod spojrzeniem" [W. Karpiński, W Central Parku, Warszawa 1989, s. 29-30]. Lenta Główczewska pisze z kolei: „Niedaleko [Piątej Alei - dop. K.Sz.] stoi ogromny hotel Plaza, a obok niego smukły wieżowiec, który wygina się ku niebu jak wklęsłe, czarne lustro. A odbija się w nim wielki hotel, domy i chmury" [L. Główczewska, Nowy Jork. Kartki z metropolii 1983-2002, przedmowa J. Hartwig, Warszawa 2004, s. 111].

32 J. Baudrillard, Ameryka, s. 92. 
nich do angielskich parków krajobrazowych. Gdy Thomas Cole, amerykański pejzażysta, porównywał krajobraz europejski z amerykańskim, wskazał na jedną podstawową różnicę, polegającą na „nie-obecności skojarzeń [w krajobrazie amerykańskim] wzbudzanych przez pejzaże starego świata": brak przydającej znaczeń i sensów kultury, dostarczającej tego, co symboliczne, oraz tego, co historyczne $^{33}$.

Baudrillard odnajduje jednak tę symbolikę w porównaniu przestrzeni do działania przemysłu filmowego. Amerykańskie miasta nie są już centrami w rozumieniu politycznym, kulturalnym i symbolicznym (instytucjonalnym), lecz "scenariuszami” do odgrywania nierzeczywistych scen z życia. Ewa Rewers, rozważając problematykę miejskich ekranów, pisze:

Usytuowany w tym przejściu człowiek (przejściu między innymi ludźmi tłoczącymi się na chodniku i lustrzaną fasadą) chętnie odwraca głowę ku ekranowi ulicy. Wszystko zostaje zorganizowane tak, aby z przechodnia stał się widzem [...]. Jedynym stałym, rozpoznawalnym obrazem wyświetlanym przez ekran miejski jest dla widza jego własne odbicie. Przechodniowi, spacerowiczowi, pasażerowi autobusu, ekrany miejskie wyświetlają bowiem film, którego bohaterem jest przede wszystkim on sam. Wchodzący w miasto widz, jak Narcyz pochylający się nad źródłem, idzie na spotkanie ze swoim odbiciem, które $\mathrm{z}$ czasem wydaje mu się bardziej realne, niż on sam ${ }^{34}$.

W tym kontekście zrozumiałe staje się porównanie amerykańskiego pejzażu do scenariusza, hologramu, trompe l'oeil - poszukując właściwych słów, Baudrillard próbuje uchwycić zjawisko, o którym pisze Rewers: przemiany podmiotu miejskiego w obraz, a miasta w skrypt podpowiadający, jakich widoków ma pragnąć przechodzień-potencjalny konsument.

Baudrillard widzi kulturę amerykańską jako prymitywną formę życia społecznego, jednocześnie jednak formę proroczą, prekursorską wobec pozostałych części rozwiniętego świata. Dziś Ameryki ma stać się jutrem Europy - słuszności tego przewidywania dowodzi ewolucja europejskich metropolii, nie tylko Paryża czy Londynu, ale również Warszawy. Małgorzata Nieszczerzewska, analizując proces przekształcania się polis w „nie-miasta”, pisze o warszawskich Złotych Tarasach:

Ich pomysłodawcą jest Jon Jerde, uznawany za guru w zakresie architektury rozrywki. Twierdzi on, że miasta współczesne może zbawić jedynie fantasy\&fun, czyli wyobraźnia i zabawa. Buduje wobec tego ogromne komercyjne malle-parki,

33 B. Frydryczak, Theodor W. Adorno: pojęcie krajobrazu kulturowego, „Estetyka i Krytyka” 2013, nr 3, s. 52.

${ }^{34}$ E. Rewers, Ekran miejski, w: Pisanie miasta, s. 50. 
w których jedzenie i zakupy stają się wydarzeniami na miarę spektakli. Projektuje architekturę zacierającą granicę między rzeczywistością a hollywoodzkim światem filmu. Złote Tarasy to wyimaginowane nie-miasto, które proponuje karnawałową atmosferę i niekończące się ciągi zdarzeń; to naszpikowana rozrywkami rodem z Hollywood metropolia ${ }^{35}$.

W ten sposób Warszawa naśladuje Nowy Jork czy Los Angeles, opisywane przez Baudrillarda już w latach osiemdziesiątych XX wieku jako przeobrażone w wielkie centra handlowe przestrzenie konsumpcji. Zgodnie z przewidywaniami Zygmunta Baumana, flâneur przemienia się w klienta shopping mallu ${ }^{36}$. Baudrillard jest wyczulony na związki krajobrazu z życiem społecznym, zauważa odpowiedniki między sposobem organizacji przestrzeni i sposobami zagospodarowania własnego ciała (pisze między innymi o zjawisku chirurgii plastycznej, modzie na sport czy obsesji zachowania cielesnego piękna) oraz relacjami społecznymi (,pustynność” krajobrazu szłaby więc $\mathrm{w}$ parze $\mathrm{z}$ alienacją jednostki i rozpadem tradycyjnych więzi). W innym miejscu autor Ameryki napisze:

Dzisiejsza abstrakcja nie jest już abstrakcją mapy, sobowtóra, lustra czy pojęcia. Symulacja nie jest już symulacją terytorium, przedmiotu odniesienia, substancji. Stanowi raczej sposób generowania - za pomocą modeli - rzeczywistości pozbawionej źródła i realności: hiperrzeczywistości. Terytorium nie poprzedza już mapy ani nie trwa dłużej niż ona. Od tej pory mapa poprzedza terytorium - precesja symulakrów - to ona tworzy terytorium i, by odwołać się ponownie do opowieści Borgesa, dziś to strzępy terytorium gniją powoli na płaszczyźnie mapy. To szczątki rzeczywistości, a nie mapy, przetrwały tu i tam ${ }^{37}$.

Proces ekspansji symulakrów obejmuje więc kategorię, zdaje się podstawową, jaką jest przestrzeń. Zwycięstwo mapy nad terytorium to oczywiście dominacja przedstawienia, obrazu, duplikatu, reprezentacji nad obecnością, oryginałem, esencją. W tym kontekście właściwe dla kultury nowoczesnej zainteresowanie mapami, ich przyrastająca lawinowo liczba, byłoby symptomem zjawiska, które diagnozuje Baudrillard. Ameryka nie jest więc teryto-

\footnotetext{
35 M. Nieszczerzewska, Miasta nie-miasta, „Kultura i Społeczeństwo” 2005, nr 1, s. 26.

36 Przemianę życia społecznego mieszkańców miast zwiazaną z konsumeryzmem i przekształceniem przestrzeni publicznej w miejsce zabawy analizuje Bauman, pisząc: „Disneyland i jego gorliwe imitacje są przykładami zdegenerowanej utopii życia jako flaneuryzmu - niezależnie od tego, jak bardzo ta utopia mogłaby być, w «klasycznej» epoce, rozproszona i nie wyartykułowana, zanim została przechwycona przez handlarzy, ponownie poddana obróbce i zamieniona w smar do przynoszącego szalone dochody wynalazku" [Z. Bauman, Przedstawienie na pustyni, s. 80].

37 J. Baudrillard, Symulakry i symulacja, przeł. S. Królak, Warszawa 2005, s. 6.
} 
rium, ale jego symulakryczna imitacją, modelem, który wygrał z pierwowzorem (o którego istnieniu iluzyjnie świadczy wyłącznie mapa - ponowoczesna mutacja iluzjonistycznego efektu trompe l'oeil).

Podobnie amerykańskie miasto i toczące się w nim życie są w ujęciu autora eseju zlepkiem filmowych scen, powielanych w niezliczonych kopiach na kolejnych ekranach od Atlantyku po Pacyfik (co przecież znacznie wcześniej diagnozuje Miłosz, pisząc o "taśmie freewayu”). Ameryka jako klisza, odbitka, pozbawiona oryginału reprodukcja to kolejny element znanego ujęcia tego przestrzenno-społecznego fenomenu (najbardziej reprezentatywnym tego znakiem, wielokrotnie przywoływanym $\mathrm{w}$ analizach, jest przecież Las Vegas, będące urbanistyczną utopią, modelowym przykładem zwycięstwa mapy nad terytorium), mitu Ameryki (szczególnie widzianej oczami Europejczyków). Podobnie pisze o swoich amerykańskich doświadczeniach także Umberto Eco, analizując zjawisko hiperrzeczywistości:

Skonstruować model w skali jeden do jednego gabinetu w Białym Domu (wykorzystując te same materiały, stosując te same kolory, ale sprawiając, że wszystko jest bardziej błyszczące, bardziej jaskrawe, nie ulegające zniszczeniu) oznacza, że aby informacja historyczna mogła być skuteczna, musi stać się reinkarnacją rzeczy, którym chce się przypisać konotację prawdziwości, rzeczy muszą zatem wydawać się prawdziwe. „Wszystko jest prawdziwe” oznacza ostatecznie „wszystko jest fałszywe". Absolutna nierealność jawi się jako rzeczywista obecność. Główną intencją rekonstrukcji gabinetu jest dostarczenie "znaku”, który nie ma jednakże uchodzić za znak: dąży on bowiem do stania się rzeczą, do unicestwienia dystansu między nim a punktem odniesienia, do eliminacji mechanizmu substytucji. Nie chodzi o obraz rzeczy, ale o jej kalkę, czyli duplikat ${ }^{38}$.

Nowy Kontynent staje się w ten sposób spacjalną wizualizacją społecznych, estetycznych i filozoficznych przeczuć Baudrillarda, dla których odnalazł on przestrzenne egzemplifikacje, stając się ponowoczesnym Tocqueville'm, w przeciwieństwie do poprzednika poszukującym nie modelu demokracji, lecz „obrazu najlepiej wyrażającego Amerykę, symbolu, który niegdyś nie był symbolem, lecz narodzinami skoncentrowanego na symbolach nowoczesnego społeczeństwa" ${ }^{39}$. Ten początek Baudrillard odnajduje w topograficznej wyobraźni - w figurze amerykańskiej pustyni.

38 U. Eco, Podróż do hiperrealności, w: tegoż, Semiologia życia codziennego, przeł. J. Ugniewska, P. Salwa, wstęp J. Ugniewska, Warszawa 1996, s. 15.

39 M. Diani, Democracy and Its Discontent: Tocqueville and Baudrillard on the Nature of "America", in: From Virgin Land to Disney World. Nature and Its Discontents in the USA Of Yesterday and Today, ed. B. Herzogenrath, Amsterdam-New York 2001, s. 54. 


\section{Bibliografia}

Augé Marc, Nie-miejsca. Wprowadzenie do antropologii hipernowoczesności, przeł. R. Chymkowski, przedm. W. J. Burszta, Warszawa: Wydawnictwo Naukowe PWN, 2010.

Baudrillard Jean, Ameryka, przeł. R. Lis, Warszawa: Wydawnictwo Sic!, 1998.

Baudrillard Jean, Symulakry i symulacja, przeł. S. Królak, Warszawa: Wydawnictwo Sic!, 2005.

Bauman Zygmunt, Przedstawienie na pustyni, przeł. M. Kwiek, w: „Drobne rysy w ciagłej katastrofie...". Obecność Waltera Benjamina w kulturze współczesnej, red. A. Zeidler-Janiszewska, Warszawa: Wydawnictwo Instytutu Kultury, 1993, s. 71-84.

Czermińska Małgorzata, Co może się zmieścić w lusterku samochodu?, w: Sztuka interpretacji. Poezja polska XX i XXI wieku, red. D. Szczukowski, G. B. Tomaszewska, Gdańsk: Słowo/Obraz Terytoria, 2014, s. 287-294.

Diani Marco, Democracy and Its Discontent: Tocqueville and Baudrillard on the Nature of "America", w: From Virgin Land to Disney World. Nature and Its Discontents in the USA Of Yesterday and Today, ed. B. Herzogenrath, Rodopi, Amsterdam-New York 2001, s. 53-68.

Eco Umberto, Podróż do hiperrealności, przeł. J. Ugniewska, w: tegoż, Semiologia życia codziennego, przeł. J. Ugniewska, P. Salwa, wstęp J. Ugniewska, Warszawa: Czytelnik, 1996, s. 11-73.

Frydryczak Beata, Theodor W. Adorno: pojęcie krajobrazu kulturowego, „Estetyka i Krytyka" 2013, nr 3, s. 43-54.

Główczewska Lenta, Nowy Jork. Kartki z metropolii 1983-2002, przedm. J. Hartwig, Warszawa: Fundacja Zeszytów Literackich, 2004.

Kalaga Wojciech, Twarz, maska, fasada, „Kultura Współczesna” 2006, nr 3 [numer zatytułowany „Kultura jako fasada”], s. 15-34.

Karpiński Wojciech, W Central Parku, Warszawa: Res Publica, 1989.

Kołodziejczyk Ewa, Amerykańskie powojnie Czesława Miłosza, Warszawa: Instytut Badań Literackich PAN, 2015.

Markowski Michał Paweł, Baudrillard: słownik, w: Jean Baudrillard, Ameryka, przeł. R. Lis, Warszawa: Wydawnictwo Sic!, 1998, s. 169-196.

Lefebvre Henri, Rhythmanalysis. Space, Time and Everyday Life, trans. S. Elden, G. Moore, introd. S. Elden, London-New York: Continuum, 2004.

Lynch Kevin, The Image of the City, Cambridge-London 1960.

Miłosz Czesław, Widzenia nad Zatoka San Francisco, Kraków: Wydawnictwo Literackie, 1989.

Nieszczerzewska Małgorzata, Miasta nie-miasta, „Kultura i Społeczeństwo” 2005, nr 1, s. $17-36$.

Nieszczerzewska Małgorzata, Narracje miejskiej wyobraźni, Poznań: Wydawnictwo Naukowe Bogucki 2009.

Rewers Ewa, Ekran miejski, Pisanie miasta-czytanie miasta, red. A. Zeidler-Janiszewska, Poznań: Wydawnictwo Fundacji Humaniora, 1997, s. 41-50. 
Sławek Tadeusz, Akro/nekro/polis: wyobrażenia miejskiej przestrzeni, w: Pisanie miasta - czytanie miasta, red. A. Zeidler-Janiszewska, Poznań: Wydawnictwo Fundacji Humaniora, 1997, s. 11-40.

Szalewska Katarzyna, Urbanalia - miasto i jego teksty. Humanistyczne studia miejskie, Gdańsk: Słowo/Obraz Terytoria, 2017.

Urry John, Socjologia mobilności, przeł. J. Stawiński, Warszawa: Wydawnictwo Naukowe PWN, 2009.

Virillo Paul, Prędkość i polityka, przeł. S. Królak, Warszawa: Wydawnictwo Sic!, 2008.

\section{"Limitless Horizontality": Topographic Imagination and Critical Discourse in Jean Baudrillard's America}

\section{Summary}

The article is an attempt to reconstruct the topographic imagination of Jean Baudrillard. The author interprets his essay, America, placing him in the context of Visions from San Francisco Bay by Czesław Miłosz. Reading America through a spatial perspective allows us not only to see the spatial imagery used to describe the landscape of the New World but also to indicate its hidden symbolism. In other words, through topographical imagery, Baudrillard verbalizes judgments about culture and history. Thus, space becomes an epistemological metaphor and the author's own philosophical dictionary.

Keywords: geopoetics, Jean Baudrillard, topographical turn, discourse, space in literature, America in literature 